\title{
ИЗУЧЕНИЕ МИКРОЦИРКУЛЯЦИИ В КОСТНОЙ ТКАНИ И ШИРИНЫ КОСТНЫХ ТРАБЕКУЛ У МЫШЕЙ С НАРУШЕНИЕЯМИ ЭНЗИМАТИЧЕСКОЙ РЕГУЛЯЦИИ ОБМЕНА СТЕРОИДНЫХ ГОРМОНОВ
}

\author{
И.С. Коклин, О.С. Гудырев, М.В. Покровский, М.В. Корокин
}

Белгородский государственный национальный исследовательский университет, ул. Победы, д. 85, г. Белгород, 308015, Российская Федерация.

DOI: 10.19163/MedChemRussia2021-2021-471

E-mail: ikoklin@mail.ru

Ввиду широкой вовлеченности кортизола в развитие патологии костной ткани, одной из потенциальных мишеней для терапевтического воздействия является система энзиматической регуляции тканевой активности стероидных гормонов. Два классических фермента, 11 $\beta$-гидроксистероиддегидрогеназа 1-го и 2-го типа (11 $\beta$-HSD 1 и 2), осуществляют пререцепторный контроль биологической активности кортизола, превращая его в неактивную 11-кетоформу (11 $\beta$-HSD 2) и обратно (11 $\beta$-HSD 1). Целью настоящего исследования явилось изучение микроциркуляции в костной ткани и состояния системы костных трабекул у мышей с генотипом 11 $\beta$-HSD2 -/- в возрасте 4 месяца. Оценку микроциркуляции проводили у мышей возрастом 4 месяцас использованием лазерной допплеровскойфлоуметрии (ЛДФ) проксимального метафиза бедренной кости, морфометрии костныхтрабекул, а также расчета коэффициента эндотелиальной дисфункции.

При проведении исследования установлено, что уровень микроциркуляции проксимального метафизабедренной кости животных с генотипом 11 $\beta$-HSD2-/относительно интактныхживотных статистически значимо уменьшался с

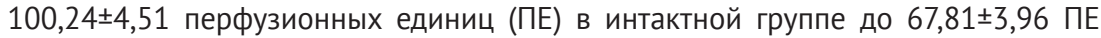
$(p<0,05)$ в группе мышей с генотипом $11 \beta-H S D 2-/-$. При проведении проб с эндотелийзависимой (в/в введение ацетилхолина) и эндотелий независимой вазодилатацией (в/в введение нитропруссида натрия) с расчетом коэффициента эндотелиальной дисфункции обнаружено увеличение КЭД с 1,23 0,13 у интактных животных до 2,75ะ0,20 животных с патологией (p<0,05). Для дальнейших морфологических исследований производился забор костного биоматериала. Гистологические срезыпроксимальных отделов бедренных костейживотных подвергали микроскопии и гистоморфометрии. Остеопоротические изменения в костях скелета были гистологически подтверждены у мышей с генотипом $11 \beta$-HSD2 -/-. При проведении микроскопии были выявлены патологические изменения в губчатой костной ткани бедра, истончение решетчатой сети костных трабекул, а также истончение и перфорацию костных пластинок. Также, мы обнаружили уменьшение средней ширины костных трабекул в губчатой тканипроксимального метафиза бедренной кости. Так, средняя ширина костных трабекул в данной локализации

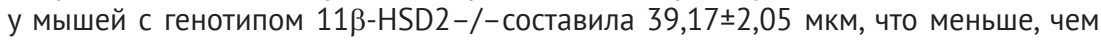
данный показатель у интактныхживотных - 67,35ะ2,94 мкм $(p<0,05)$. 